\title{
The Level of Compliance of Commercial Motorcyclists to Traffic Rules on Urban Roads in South Western Nigeria
}

\author{
Musilimu Adeyinka Adetunji \\ Department of Geography, Faculty of Arts and Social Sciences, \\ Federal University Lokoja, Kogi State, Nigeria \\ Email: musilimuadetunji@yahoo.com
}

Oluwole Aloba

Professor of Geography, Department of Geography, Obafemi Awolowo University, Ile- Ife

\section{Doi:10.5901/jesr.2014.v4n3p345}

\begin{abstract}
The occurrence of traffic accidents involving commercial motorcyclists now characterizes urban transport in many developing countries and has become a major public concern. Yet the use of motorcycles as a means of urban transport continues to attract increasing patrons because of its flexibility and fastness in reaching less accessible parts of the cities of the third world countries. This paper examines the characteristics and the level of safety awareness of commercial motorcyclists in three major urban centres in South-Western Nigeria. Primary and secondary sources of data were used for this research. One hundred and twenty (120) well-structured questionnaires were administered on systematically selected commercial motorcyclists operating from major road junctions and motor parks in Ilesa, Iwo and Osogbo. Both descriptive and inferential statistics used in analyzing the data. The findings reveals that the "care free attitudes" of most commercial motorcyclists towards their own safety as well as their passengers is hinged on lack of adequate training and the value illegal possession of driving licenses by this category of urban transport operators. The paper advocates for policies to control, enforce and regulate the activities of commercial motorcyclists by relevant government security agencies such as the Federal Roads Safety Corps.
\end{abstract}

Keywords: Safety, Awareness, Accidents, Attitude and Motorcycle Operators

\section{Introduction}

Traffic accidents caused by commercial motorcyclists are common occurrence on many urban roads in Nigeria and elsewhere in the developing world. They have been known to be responsible for a large percentage of orthopedic patients in some urban hospitals (Ogunjumo, 1990: Gbadamosi, 2006). The general acceptance of motorcycles as a mode of passenger transport in Nigeria was as a result of two factors. One, the introduction of the Structural Adjustment Programme (SAP) in 1986 made the purchase of cars for use as taxis beyond the reach of many ordinary Nigerian taxi operators. Two, rapid growth and expansion of many urban centres in Nigeria following the spate of state creation in the 1980s and 1990s led to increased mobility of the urban population which in turn put pressure on exiting poor urban transport infrastructure and hence the need to adopt a relatively more flexible mode of transport in urban areas. Motorcycle which has been in use in other parts of the developing world especially in Asia as a commercial transport provided a readymade solution to the high rate of urban transportation demands. In recent times however, the frequent occurrence of traffic accidents caused by commercial motorcyclists in urban centres in Nigeria has led to a national debate on the suitability of this mode of transport in the urban space, particularly on the safety of the operators and their passengers. For example, despite the use of head helmets, the Lagos State Government and the authority of the Federal Capital Territory have banned the activities of commercial motorcyclists on some of their roads due to increased reports of traffic road accidents and day light robbery perpetrated by commercial motorcyclists. Thus, the aim of this paper is to examine the level and extent of compliance of commercial motorcyclists with traffic regulations in order to determine their safety awareness and subsequently reduce the occurrence of traffic accidents on urban roads in Nigeria. The paper is based on a study carried out in parts of southwestern Nigeria. 


\section{Theoretical Framework and Literature Review}

Theoretically, the modal split model provides a useful explanation of travel behavior particularly with regard to choice of travel mode. According to the model, different modes of urban transport are available and open to trip makers. These include cars, buses, taxis, trains, walking and various types of mechanical and non-mechanical cycles. The choice of any of these modes by an urban commuter is influenced by such factors as trip length, trip type, trip purpose, socio-economic characteristics of the trip maker (income, age, automobile ownership, and residential density), route length, modal availability, modal affordability and modal comfortability (Ogunsanya, 1986; Okonko, 2000).

The choice of motorcycle as a popular mode of urban transportation in Nigeria can be attributed to its cheap cost of buying a new one as well as low cost of maintenance. Those who repair them are ubiquitous. Their spare parts are also common and easily moved around (Ogunjumo, 1990). Besides, motorcycles possess a number of unique features such as narrow width, small size, high power to weigh ratio and intuitive steering which make them much more flexible to maneuver especially on rough urban roads than other motorized modes of transport. Lee (2007) has observed that motorcycles provide freedom in a traffic stream. In order to get to their destinations at a short possible time, their operators generally do not obey traffic rules. Commercial motorcyclists have little regards for other road users which often lead to traffic accidents on urban roads (Gbadamosi, 2006). A review of some of the previous studies on the operations of commercial motorcyclists in Nigeria has focused attention on its importance as an alternative means of transport for inter-rural and rural-urban travel in order to meet the travel demands of rural population (Oyesiku and Odufuwa, 2002: Adeniji, 1987), as well as the affordability, maintenance cost and willingness of the society to embrace the use of motorcycles for public transport compared to the commercial vehicles (Central Bank of Nigeria, 2006: Fasakin, 2000; 2001)

More importantly, the percentage of imported motorcycles (all vehicles) increased astronomically from $10.37 \%$ in 1999 to $47.82 \%$ in 2003 and again declined to 36.68\% in 2004(Central Bank of Nigeria, 2006). For instance, approximately $\$ 164$ million was allocated to the importation of motorcycles and bicycles in 1999. This figure increased astronomically to $\$ 849$ million in 2000 . This implied that a huge sum of money was allocated for the importation of nonmotorized modes of transports particularly motorcycles and bicycles so as to meet the travel demands of the populace which have increased sharply over the past three decades. This has led to influx of large numbers of motorcycles in urban centres in Nigeria. The number of registered motorcycles increased tremendously from 218,802 in 2001 to 288,474 in 2004 (Gbadamosi, 2006). Therefore, this paper examines the mode of operations of commercial motorcyclists in some major urban centres in Osun state in Southwestern Nigeria with a view to improving the awareness of its operators on traffic rules and regulations and subsequently promotes sustainable transport development and reduces traffic accidents on urban centres in Nigeria.

\section{Study Area}

The study area consists of three major urban centres in Osun State. The most urban centre was selected from each of the three Senatorial Districts in the State. The selected centres are llesa (Osun East), Osogbo (Osun Central) and Iwo (Osun West). These cities have similar urban characteristics such as patterns of land use, urban spatial structure, population size and economic activities. Before the 1960s, the spatial structure of Osogbo, Ilesa, Iwo and many others with similar population sizes in Nigeria followed the old European cities which were concentric in nature with foot paths linking major activity centres. For example, on Ibadan, Mabogunje (1968) reported how such concentric pattern was broken up by the emerging transportation road networks in and around the city. The Oba's (king's) palace in many traditional cities especially in Southwestern Nigeria was usually centrally located. All the roads originating from neighboring villages and towns terminated at the palace (Ogunsanya, 2004; Peel, 1983). The residential houses located around the king's palace served as the central business districts (CBD). And to a large extent this type of land- use patterns affected the transportation network and household travel demands (Adetunji, 2010). Thus, the land-use arrangement in many urban centres in Nigeria predated the advent of automobile which according to Ogunsanya (2002) either make or break up cities. For instance, the locations of the Government Secretariat, educational institutions, hospitals and industries became possible as a result of increased motorization and personal mobility. One major consequence of this traffic in towns and cities was the need to create new right-of-way for the road users in order to gain access to different urban activity centres (Olatubara, 1997). The new development especially following the introduction of the Structural Adjustment Programme in 1986 encouraged the use of motorcycles as a new mode of public transport in both rural and urban centres in Nigeria. The general acceptability of motorcycles is further promoted as a result of its 
flexibility in providing door to door service even on many poor urban roads. This study therefore sets to examine the operation of commercial motorcyclists in some of Nigeria's traditionally but economically vibrant cities whose political changing fortunes either as state capitals or Local Government Headquarters have been in the upward swing in recent years.

\section{Research Methodology}

As earlier stated, one major urban centre from each of the three Senatorial Districts in Osun State based on their populations and other factors such as political status either as state capital or Local Government Headquarters was selected for detailed study. The selected cities include llesa (Osun East), Osogbo (Osun Central) and Iwo (Osun West). The research made use of data that were collected from both primary and secondary sources. To this end, a structured questionnaire was used to gather information from every $20^{\text {th }}$ commercial motorcyclist found along major road intersections in the three cities. In addition, forty motorcyclists based in the most strategically located park in each of the three urban areas were interviewed. A total of one hundred and twenty (120) commercial motorcyclists were interviewed. Their responses were subsequently analyzed using both descriptive and inferential statistics such as Analysis of Variance and Regression analysis.

\section{Results and Discussions}

The result of analysis shows that motorcycle operators are not only males but also young adults, with large family size. Table 1 below reveals that more than 84\% of the commercial motorcyclists interviewed were less than 40years of age, while the rest are between ages 41 and 60 years. However, the age structure varies from one city to another. For instance, in Iwo, $47.2 \%$ of the motorcycle operators are young boys of less than 20years of age, whereas in Osogbo and llesa operators of the same age group constitute only $12.9 \%$ and $4.8 \%$ respectively.

Table 1: Socioeconomic Characteristics of motorcycle operators in the study area

\begin{tabular}{|c|c|c|c|c|}
\hline Town/City & \multicolumn{3}{|c|}{ Age of Respondents } & \\
\hline & $<20 y r s$ & 21-40yrs & 41-60yrs & Total \\
\hline Ilesa & $4.8 \%$ & $61.9 \%$ & $33.3 \%$ & $100.0 \%$ \\
\hline IWO & $47.2 \%$ & $43.4 \%$ & $9.4 \%$ & $100.0 \%$ \\
\hline Osogbo & $12.9 \%$ & $74.2 \%$ & $12.9 \%$ & $100.0 \%$ \\
\hline Total & $28.6 \%$ & $56.2 \%$ & $15.2 \%$ & $100.0 \%$ \\
\hline Town/City & \multicolumn{3}{|c|}{ Family Size } & Total \\
\hline & $1-2$ & $3-4$ & $>5$ & \\
\hline Ilesa & $33.3 \%$ & $61.9 \%$ & $4.8 \%$ & $100.0 \%$ \\
\hline Iwo & $33.0 \%$ & $24.5 \%$ & $41.5 \%$ & $100.0 \%$ \\
\hline Osogbo & $16.1 \%$ & $45.2 \%$ & $38.7 \%$ & $100.0 \%$ \\
\hline Total & $28.6 \%$ & $38.1 \%$ & $33.3 \%$ & $100.0 \%$ \\
\hline
\end{tabular}

In most developed economies with sustained transport policies, motorcyclists like all other would be motorists are expected to be formally trained at the end of which they are given valid papers confirming their competency to operate on various categories of roads. The reverse is the case in developing countries where authorities in charge of vehicular operators do little or nothing to monitor motorcyclists who in most cases do not carry valid papers on them. For instance, table 2 indicates that $66.2 \%$ of the motorcycle operators spent less than two weeks on learning how to operate on the highways. Another $23.8 \%$ spent between 2 and 4 weeks, while only $9.5 \%$ of commercial motorcyclists spent more than 4weeks on how to effectively operate a motorcycle. Majority of the motorcyclists interviewed $-67.2 \%$ claimed to have been operating for over three years, as low as $32.8 \%$ of the operators have more than three year experience as commercial motorcyclists on urban roads. 
Table 2: Shows the length of time motorcyclists spent learning on how to operate their machines before putting them on the road.

\begin{tabular}{|l|c|c|c|c|}
\hline \multirow{2}{*}{ Town/City } & \multicolumn{2}{|c|}{ length of time spent on how to operate motorcycles before operating on intra-urban roads } & \multirow{2}{*}{ Total } \\
\cline { 2 - 5 } & $<2$ weeks & $2-4$ weeks & $>4$ weeks & $100.0 \%$ \\
\hline Ilesa & $33.3 \%$ & $52.4 \%$ & $14.3 \%$ & $1.9 \%$ \\
\hline Iwo & $92.5 \%$ & $5.7 \%$ & $19.4 \%$ & $100.0 \%$ \\
\hline Osogbo & $45.2 \%$ & $35.5 \%$ & $9.5 \%$ & $100.0 \%$ \\
\hline Total & $66.7 \%$ & $23.8 \%$ & $>3$ years & \multirow{2}{*}{ Total } \\
\hline \multirow{2}{*}{ Town/City } & \multicolumn{2}{|c|}{ How long have you been operating motor cycle on the } & intra-urban roads & $100.0 \%$ \\
\cline { 2 - 5 } & 1 year & $2-3 \quad$ Years & $23.8 \%$ & $100.0 \%$ \\
\hline Ilesa & $38.1 \%$ & $38.1 \%$ & $34.0 \%$ & $100.0 \%$ \\
\hline Iwo & $22.6 \%$ & $43.4 \%$ & $35.5 \%$ & $100.0 \%$ \\
\hline Osogbo & $9.7 \%$ & $54.8 \%$ & $32.4 \%$ & \\
\hline Total & $21.9 \%$ & $45.7 \%$ & & \\
\hline
\end{tabular}

The research also shows that many of the motorcycle operators do not possess any form of driving papers of competency before starting to operate as commercial motorcyclists. Table 3 reveals that $52.3 \% 0$ of those interviewed have no license to operate. Bulk of the remaining $47.3 \%$ got their licenses through illegal means. This implies that as high as this percentage would invariably constitute risk to urban commuters. A city by city analysis shows that those with valid driving licenses vary from $57.1 \%$ in llesa to $41.9 \%$ and $28.3 \%$ in Osogbo and Iwo respectively. Unfortunately, traffic officers unusually turn bland eyes to these traffic offenders once they are offered a small amount of money.

Table 3: Motorcyclists operators with driving license

\begin{tabular}{|l|c|c|c|}
\hline \multirow{2}{*}{ Town/City } & \% of Driving License owners among commercial motorcyclists? & \multirow{2}{*}{ Total } \\
\cline { 2 - 3 } & Yes & No & $100.0 \%$ \\
\hline Ilesa & $57.1 \%$ & $42.9 \%$ & $100.0 \%$ \\
\hline Iwo & $28.3 \%$ & $71.7 \%$ & $100.0 \%$ \\
\hline Osogbo & $41.9 \%$ & $58.1 \%$ & $100.0 \%$ \\
\hline Total & $38.0 \%$ & $62.0 \%$ & \\
\hline
\end{tabular}

As a result of high unemployment among urban youths in Nigeria, many of them are encouraged to take up commercial motorcycle business. The field survey shows that each operator makes enough money to keep body and soul together even though majority complained that bulk of their earnings are spent on bribing the police, their union leaders and on procuring spear parts. Table 4 indicates that on the whole about $53 \%$ of operators earn less than $\# 2,000$ per day. In Osogbo and llesa $77.4 \%$ and $66.7 \%$ interviewed earned less than 2000 naira per day respectively. Further analysis reveals that $21 \%$ of the operators earned between $\# 2,000$ and $\# 3,000$ per day, while a significant proportion of commercial motorcyclists (28.6\%) earned more than \#3,000 per day. This implies that a commercial motorcyclist earns more than a Graduate Assistant in a Nigerian university. (Arosanyin \& Ipingbemi, 2010). Iwo has the highest (50.6\%) operators in this category of high income earners among motorcyclists in the study area.

Table 4: Income of the motorcycle operators

\begin{tabular}{|l|c|c|c|c|}
\hline \multirow{2}{*}{ Town/City } & \multicolumn{2}{|c|}{ Earnings Per day of Commercial motorcyclists in the Srudy Area } & \multirow{2}{*}{ Total } \\
\cline { 2 - 4 } & $\mathrm{N} 2,000$ & $\mathrm{~N} 2,000-\mathrm{N} 3,000$ & $>\mathrm{N} 3,000$ & \\
\hline Ilesa & $66.7 \%$ & $33.3 \%$ & $0.0 \%$ & $100.0 \%$ \\
\hline Iwo & $28.3 \%$ & $15.1 \%$ & $56.6 \%$ & $100.0 \%$ \\
\hline -Osogbo & $77.4 \%$ & $22.6 \%$ & $0.0 \%$ & $100.0 \%$ \\
\hline Total & $50.5 \%$ & $21.0 \%$ & $28.6 \%$ & $100.0 \%$ \\
\hline
\end{tabular}

Further analysis shows that the operators have experienced various degrees of injuries in the past, for instance, Table 5 revealed that as high as $40 \%$ of the operators have experienced one form of accidents or other within the last three months. This however varies from one city to another. For instance, $58.1 \%, 57.10 \%$ and $22.9 \%$ agreed to have been involved in accidents in Osogbo, llesa and Iwo respectively. The magnitude of the accidents involved by the operators 
varied from fatal to minor injuries. About $59 \%$ of the operators claimed that they have sustained fatal injuries, while $41 \%$ have had minor accidents.

Table 5: Motorcycle accidents and injuries sustained by the operators in the study area

\begin{tabular}{|l|c|c|c|}
\hline \multirow{2}{*}{ Town/City } & \multicolumn{3}{|c|}{$\%$ involved in road accidents on motorcycle in study area } \\
\hline & Yes & No & Total \\
\hline Ilesa & $57.1 \%$ & $42.9 \%$ & $100.0 \%$ \\
\hline Iwo & $22.6 \%$ & $77.4 \%$ & $100.0 \%$ \\
\hline Osogbo & $58.1 \%$ & $41.9 \%$ & $100.0 \%$ \\
\hline Total & $40.0 \%$ & $60.0 \%$ & $100.0 \%$ \\
\hline Town/City & \multicolumn{2}{|c|}{$\%$ of operators with injuries in the study area } \\
\hline & Yes & No & Total \\
\hline Ilesa & $57.1 \%$ & $42.9 \%$ & $100.0 \%$ \\
\hline Iwo & $54.7 \%$ & $45.3 \%$ & $100.0 \%$ \\
\hline Osogbo & $67.7 \%$ & $32.3 \%$ & $100.0 \%$ \\
\hline Total & $59.0 \%$ & $41.0 \%$ & $100.0 \%$ \\
\hline
\end{tabular}

The injuries usually sustained are often fatal because many of the operators do not wear head helmets. Table 6 reveals that only $55.2 \%$ of the operators claimed to be wearing head helmets, while the remaining $44.8 \%$ do not protect their heads in of any form of crash. Further analysis shows that a large proportion (62.3\%) of the operators in Iwo does not wear head helmets. The survey reveals that $38 \%$ of the culprits were set free, $23 \%$ were fined, and $12.3 \%$ were charged to court while the remaining $17.1 \%$ of the operators have their motorcycles confiscated.

Table 6: Attitudes of the motorcyclists towards helmet wearing and the punishment melted against offenders

\begin{tabular}{|c|c|c|c|c|c|}
\hline \multirow{2}{*}{ Town/City } & \multicolumn{4}{|c|}{$\%$ of Respondents Wearing Head Helmets in the Study Area } & \multirow{2}{*}{ Total } \\
\hline & \multirow{2}{*}{\multicolumn{2}{|c|}{$\begin{array}{c}\text { Yes } \\
52.4 \%\end{array}$}} & & No & \\
\hline Ilesa & & & & $47.6 \%$ & $100.0 \%$ \\
\hline Iwo & \multicolumn{2}{|c|}{$37.7 \%$} & & $62.3 \%$ & $100.0 \%$ \\
\hline Osogbo & \multicolumn{2}{|c|}{$87.1 \%$} & & $12.9 \%$ & $100.0 \%$ \\
\hline Total & \multicolumn{2}{|c|}{$55.2 \%$} & & $44.8 \%$ & $100.0 \%$ \\
\hline \multirow{2}{*}{ Town/City } & \multicolumn{4}{|c|}{ Percentage of Types of Punishments Meted out to Offenders } & Total \\
\hline & Not applicable & Fine & Charge to Court & Confiscation of motorcycle & Total \\
\hline Ilesa & $47.6 \%$ & $19.1 \%$ & $0.0 \%$ & $33.3 \%$ & $100.0 \%$ \\
\hline Iwo & $45.3 \%$ & $7.5 \%$ & $24.5 \%$ & $24.5 \%$ & $100.0 \%$ \\
\hline Osogbo & $19.4 \%$ & $54.8 \%$ & $0.0 \%$ & $6.5 \%$ & $100.0 \%$ \\
\hline Total & $38.1 \%$ & $23.8 \%$ & $12.4 \%$ & $17.1 \%$ & $100.0 \%$ \\
\hline
\end{tabular}

\subsection{Variation in Attitudes of Motorcycle Operators across different Cities in the Study Area}

\subsubsection{Hypothesis Testing}

Ho : There is no significant relationship between the operators apprehended by any law enforcement agent for violating traffic rules( Income Earning, Helmet Wearing, Length of Trainings and Possession of Driving License), across difference city in the study area.

Ho: There is significant difference.

Table 7 revealed that the results of the analysis of variance is significant at (Income Earning $F=3.62, p<.00$; Helmet Wearing $F=1.54, p<.22$; Length of Trainings $F=4.47, p<.04$ and Possession of Driving License $F=1.21, p<.27$ ), across difference cities in the study area. 
Table 7: Results of analysis of Variance - ANOVA

\begin{tabular}{|c|c|c|c|c|c|c|}
\hline & & Sum of Squares & Df & Mean Square & $\mathrm{F}$ & Sig. \\
\hline How much are you Earning per day? & $\begin{array}{l}\text { Between Groups } \\
\text { Within Groups } \\
\text { Total }\end{array}$ & $\begin{array}{c}2.417 \\
82.175 \\
84.592\end{array}$ & $\begin{array}{c}1 \\
123 \\
124\end{array}$ & $\begin{array}{r}2.417 \\
.668\end{array}$ & 3.617 & .060 \\
\hline $\begin{array}{l}\text { Have you experience accident on Motorcycle (okada) } \\
\text { before? }\end{array}$ & $\begin{array}{l}\text { Between Groups } \\
\text { Within Groups } \\
\text { Total }\end{array}$ & $\begin{array}{c}.056 \\
30.856 \\
30.912\end{array}$ & $\begin{array}{c}1 \\
123 \\
124\end{array}$ & $\begin{array}{l}.056 \\
.251\end{array}$ & .225 & .636 \\
\hline Do you normally wear Helmet? & $\begin{array}{l}\text { Between Groups } \\
\text { Within Groups } \\
\text { Total }\end{array}$ & $\begin{array}{c}.370 \\
29.630 \\
30.000\end{array}$ & $\begin{array}{c}1 \\
123 \\
124\end{array}$ & $\begin{array}{l}.370 \\
.241\end{array}$ & 1.537 & .217 \\
\hline Do you take Motorcycles (okada) as a permanent job? & $\begin{array}{l}\text { Between Groups } \\
\text { Within Groups } \\
\text { Total }\end{array}$ & $\begin{array}{c}.258 \\
30.542 \\
30.800\end{array}$ & $\begin{array}{c}1 \\
123 \\
124\end{array}$ & $\begin{array}{l}.258 \\
.248\end{array}$ & 1.040 & .310 \\
\hline $\begin{array}{l}\text { How many times have you been involved in accidents on } \\
\text { okada within the last } 6 \text { months? }\end{array}$ & $\begin{array}{l}\text { Between Groups } \\
\text { Within Groups } \\
\text { Total }\end{array}$ & $\begin{array}{c}.184 \\
45.816 \\
46.000\end{array}$ & $\begin{array}{c}1 \\
123 \\
124\end{array}$ & $\begin{array}{l}.184 \\
.372\end{array}$ & .495 & .483 \\
\hline Do you have driving licensee? & $\begin{array}{l}\text { Between Groups } \\
\text { Within Groups } \\
\text { Total }\end{array}$ & $\begin{array}{c}.320 \\
32.480 \\
32.800\end{array}$ & $\begin{array}{c}1 \\
123 \\
124\end{array}$ & $\begin{array}{l}.320 \\
.264\end{array}$ & 1.211 & .273 \\
\hline $\begin{array}{l}\text { What was the length of training you underwent before } \\
\text { you started riding motorcycle? }\end{array}$ & $\begin{array}{l}\text { Between Groups } \\
\text { Within Groups } \\
\text { Total }\end{array}$ & $\begin{array}{c}1.753 \\
48.247 \\
50.000\end{array}$ & $\begin{array}{c}1 \\
123 \\
124\end{array}$ & $\begin{array}{c}1.753 \\
.392\end{array}$ & 4.470 & .037 \\
\hline Have you sustained any injury on okada before & $\begin{array}{l}\text { Between Groups } \\
\text { Within Groups } \\
\text { Total }\end{array}$ & $\begin{array}{c}.000 \\
29.792 \\
29.792 \\
\end{array}$ & $\begin{array}{c}1 \\
123 \\
124\end{array}$ & $\begin{array}{l}.000 \\
.242\end{array}$ & .001 & .975 \\
\hline
\end{tabular}

\section{Conclusion and Recommendations}

The study examined the operations and safety awareness of motorcycles operators in major urban centres in Osun State namely, Osogbo, llesa and Iwo. The study showed that the operators were mostly young men with over $84 \%$ under 40years of age. The irrational behavior of commercial motorcyclists on urban roads indicates inadequate training and illegal possession of driving license as well as the inability of the Police to enforce traffic rules and regulations among this category of transporters in urban centres in Nigeria. All this has led to traffic accidents in these urban centres in developing countries. With the exception of Lagos State and part of the Federal Territory, there is little or no serious government policy addressing the operations of commercial motorcyclists with a view to cutting down the rate of motorcycles accidents in urban centres in Nigeria. However, there is need to review the possession of driving license and enforce compliance by commercial motorcyclists who are operating in the cities. More importantly operators should be forced to wear head helmets whenever on duty. One way to do this is to subsidize the cost of helmets and other kits so that operators can have full access to all they need for effective operation. Also, there is need to have accurate data on accident cases at local, State and Federal levels in the country. As of now many accidents are never reported for fear of prosecution by the police. The paper therefore concludes by advocating specific government policy to regulate the operation of commercial motorcyclists on intra-urban roads and empower all law enforcement agencies to ensure that commercial motorcyclists obey and comply with all traffic rules and regulations.

\section{References}

Adeniji, kunle. 1985. "Urban Transport System in Nigeria " ODU-Journal of West Africa Studies; No.28, pp 81-97.

Adetunji, M.A. 2010. Spatial analysis of urban mobility patterns in llesa, Osun State. A PhD Thesis submitted to the Department of Geography, Obafemi Awolowo University, Ile-Ife. pp. 273

Arosanyin, G.T and Ipingbemi, O. 2007. Car Wash Service in Nigeria's Road Transport System: Evidence from Ilorin. Nigerian Institute of Social and Economic Research, (NISER) Vol.49 No.1 pages 45-64

Central Bank of Nigeria ' December', 2006. Statistical Bulletin in National Bureau of Statistics (nbs). Annual Abstract of Statistical table 349.2 .

Fasakin,J.O. 2000. Daily Cost Considerations in the Operations of Commercial Motorcycles in Nigeria; A Location Analysis for Akure 
township Transportation Research part A policy and Practice, Volume.8, pp.189-202.

Fasakin J.O. 2001 Some Factors Affecting Daily Profits of Commercial Motorcycles in Akure Nigeria Transport Policy Vol.8 pp 63-69.

Federal Republic of Nigeria. 1975. Second National Development Plan -1970-74 pp.219. Lagos Federal Ministry of Information.

Mabogunje, A.L 1968. Urbanization in Nigeria. University of London Press Limited. Pp353

Olatubara, C.O. 1997. Urban Residential Mobility: The Mover and Non-Mover Discriminant Factors", Nigerian Journal of Economic and Social Studies, Vol. 39, No.2, pp. 169 - 181.

Ogunjumo, A. 1990. Urban Transportation Dilemma in Nigeria" SPACE, Journal of School of Planning and Architecture, New Delhi, 5 , $3 \& 4,100-106$

Ogunsanya, A. A: Vandu-Chikolo, I and Sumaila, A.G. 2004. Perspectives on Urban Transportation in Nigeria. Nigeria Institute of Transport Technology (NITT), Zaria. M O D Press, Kaduna pp1-26

Okonko,E. 2000. Motorcycle commuting deterrents: A study of Motorcycle Accidents in Akure, Nigeria. International Journal of Urban and Regional Affairs Vol.14 No 2.

Oyesiku, O. K. and Odufuwa, B. O. 2002. Gender Perspectives in Travel Behaviors of motorcycle passengers in Nigerian Intermediate Cities. In Godard, X. and Fatonzoun, I.(eds.) Urban Mobility for All. Lisse, The Netherlands: A. A. Balkema (Swets \& Zeitlinger B. V.), pp. $13-19$.

Peel, J.D.Y. 1983. Ijesas and Nigerians': The Incorporation of a Yoruba Kingdom 1890s. Cambridge University Press (1983) CambridgeLondon pp.333

Tzu-Chang Lee. 2007. An Agent-Based Model to Stimulate Motorcycle Behaviors in Mixed Traffic Flow. A thesis submitted for the degree of Doctor of Philosophy of the University of London 
